\title{
Detrital zircon geochronologic tests of the SE Siberia-SW Laurentia paleocontinental connection
}

\author{
J. S. MacLean ${ }^{1}$, J. W. Sears ${ }^{1}$, K. R. Chamberlain ${ }^{2}$, A. K. Khudoley ${ }^{3}$, A. V. Prokopiev ${ }^{4}$, A. P. Kropachev ${ }^{5}$, and \\ G. G. Serkina ${ }^{3}$ \\ ${ }^{1}$ University of Montana, Missoula, Montana 59812, USA \\ ${ }^{2}$ University of Wyoming, Laramie, Wyoming 82070, USA \\ ${ }^{3}$ St. Petersburg State University, Geological Department, University nab. 7/9, St. Petersburg, 199034, Russia \\ ${ }^{4}$ Diamond and Precious Metal Geology Institute SB RAS, Lenin Avenue 39, Yakutsk, 677980, Republic \\ Sakha (Yakutia), Russia \\ ${ }^{5}$ All Russian Geological Research Institute (VSEGEI), Sredniy Prospect 74, St. Petersburg, 199106, Russia
}

\begin{abstract}
Strikingly similar Late Mesoproterozoic stratigraphic sequences and correlative U-Pb detrital-zircon ages may indicate that the Sette Daban region of southeastern Siberia and the Death Valley region of southwestern North America were formerly contiguous parts of a Grenville foreland basin. The Siberian section contains large numbers of detrital zircons that correlate with Grenville, GraniteRhyolite, and Yavapai basement provinces of North America. The sections in both Siberia and Death Valley exhibit west-directed thrust faults that may represent remnants of a Grenville foreland thrust belt. North American detritalzircon components do not occur in Siberian samples above a $\sim 600 \mathrm{Ma}$ breakup unconformity, suggesting that rifting and continental separation blocked transfer of clastic sediment between the cratons by 600 Ma. Faunal similarities suggest, however, that the two cratons remained within the breeding ranges of Early Cambrian trilobites and archeocyathans.
\end{abstract}

\section{Introduction}

Close similarities in Siberian and North American basement provinces suggest that these cratons may have occupied contiguous parts of a Proterozoic supercontinent before the Siberian craton drifted away to become embedded in the Eurasian landmass. For nearly 30 years geologists have, however, disagreed upon the exact linkages of these cratons, and have published a bewildering array of Proterozoic continental reconstructions (Sears and Price, 1978, 2003; Hoffman, 1991; Condie and Rosen, 1994; Rainbird et al., 1998;

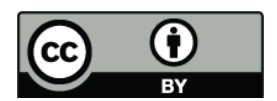

Correspondence to: J. W. Sears

(james.sears@umontana.edu)
Frost et al., 1998; Ernst et al., 2000). Because of its large size and rich geological and paleontological heritage, the correct reconstruction of the Siberian-North American craton would constrain numerous ancillary problems in Earth science, ranging from the origin and dispersal of metazoans (e.g. Bowring et al., 1993) to the long-term behavior of the magnetic field (e.g. Kirschvink et al., 1997).

The reconstruction of Sears and Price (2003) tightly fits the eastern Siberian craton against the western North American craton, and connects several Proterozoic piercing points between the two cratons (Fig. 1). The reconstruction aligns hingelines and Neoproterozoic isopachs of the Sette Daban basin of southeastern Siberia and the southwestern Cordilleran miogeocline. It predicts that the Sette Daban basin of Siberia (Khudoley et al., 2001) was contiguous with Death Valley. We undertook joint Russian-American excursions to Sette Daban and Death Valley to compare the lithostratigraphy of these basins, and collected specimens for detrital zircon $\mathrm{U}-\mathrm{Pb}$ age dating. We separated detrital zircons from sandstone samples and used standard techniques to U$\mathrm{Pb}$ date them at the Stanford University-US Geological Survey SHRIMP facility and at the LAICPMS facility at Washington State University. We analyzed selected grains at both facilities and found that the two techniques gave equivalent $\mathrm{Pb}-\mathrm{Pb}$ ages at the 2-sigma confidence level. Our conclusions are based on 780 detrital-zircon grains with $\mathrm{Pb}-\mathrm{Pb}$ ages that were $<10 \%$ discordant. See MacLean (2007) for full tabulations of our geochronological data.

Our results suggest that matching sequences of Mesoproterozoic strata in Sette Daban and Death Valley may have been deposited within a single intracratonic basin. Our results further suggest that the basin may have rifted in Late Neoproterozoic time, after which detrital zircons did not cross between the Siberian and North American cratons.

Published by Copernicus Publications on behalf of the European Geosciences Union. 


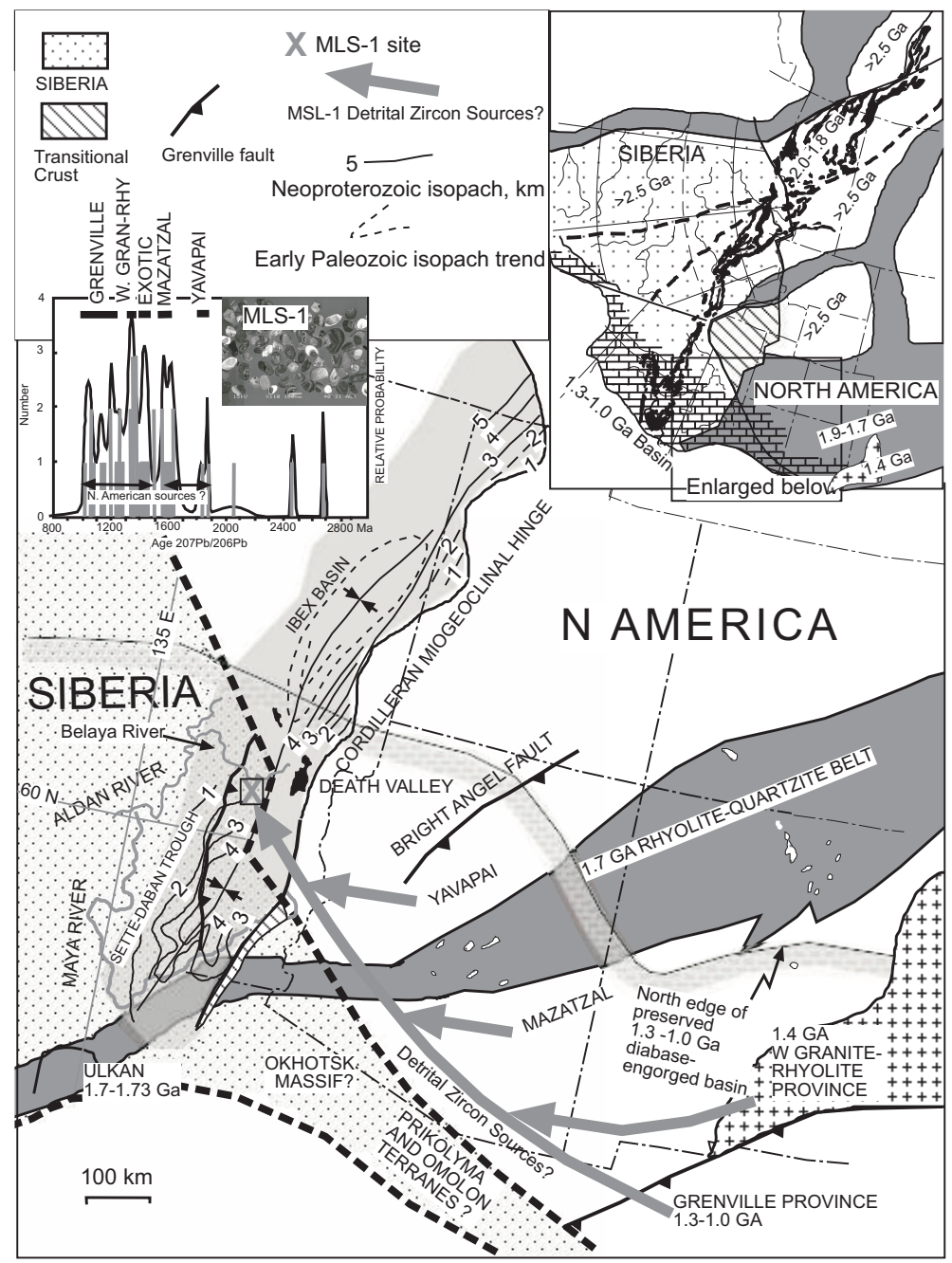

Fig. 1. Proterozoic connection between Siberian and North American cratons after Sears and Price (2003). Death Valley restores against Sette Daban basin of Siberia. Gray arrows show possible transport of sediment down rift from Grenville, Granite-Rhyolite, and Yavapai basement provinces to Sette Daban basin, where correlative detrital zircons were found, for example in Siberian sample MLS-1 (inset). Small black arrows identify trough axis at margin between reconstructed continents. Death Valley and White-Inyo positions (black spots) restored after Levy and Christie-Blick (1993). Sette Daban isopachs after Khudoley et al. (2001). Transitional crust shown in inset after Khudoley and Prokopiev (2007).

\section{Lithostratigraphic matches}

The Mesoproterozoic basins of Sette Daban and Death Valley contain remarkably similar lithostratigraphic sequences, although the Sette Daban section is approximately three times thicker (Fig. 2). The pertinent part of the Siberian section includes, from the base up, the Aimchan, Kerpyl, Lakhanda, and Uy groups (Khudoley et al., 2001). Its North American counterpart comprises, from the base up, the Crystal Spring, Beck Spring, and lower Kingston Peak (KP1 of Prave, 1999) formations of the Pahrump Group (Link, 1993).

The Aimchan Group closely resembles the lower part of the Crystal Spring Formation; both have basal troughcrossbedded sandstone and conglomerate overlain by red shale and pinkish-orange weathering, cherty, stromatolitic dolomite, capped by remarkably similar beds of branching stromatolites. The overlying Bik Formation of the lower Kerpyl Group matches the upper part of the Crystal Spring Formation. Each overlies a karstified surface and locally includes $\mathrm{dm}$-thick beds of distinctive conglomerate at the base, with pebbles of blue quartz and dolomite, succeeded by blocky-fracturing, trough-crossbedded quartzite, and red shale with thin white quartzite beds.

The upper Kerpyl and Lakhanda groups meticulously match western facies of the Beck Spring Formation that are exposed in the Ibex Hills of southwest Death Valley. Both sections consist of five or six variegated siliciclasticdolomite cycles that are each made up of numerous smaller cycles. In each section, a typical cycle begins with yellowweathering, grey shale, followed in order by yellow or 
orange-weathering laminated dolomite, grey microlaminated dolomite, and black, bituminous, microlaminated and stromatolitic dolomite. The Death Valley section includes micaceous and feldspathic sandstone at the bases of some cycles. The eastern facies of both sections include thick dolomite characterized by solution-collapse breccias and distinctive 2 3-m tall microbial mounds with flanking roll-up slump structures and breccias. This facies characterizes the Beck Spring Formation in the Alexander Hills and Kingston Range of the Death Valley region (Abolins et al., 2000).

The Lakhanda Group grades upward into the Uy Group, a kms-thick grey shale and sandstone succession. The Beck Spring Formation passes up into similar grey shale and sandstone of the transition beds of the lower Kingston Peak Formation (KP1) that Prave (1999) considers related to the Beck Spring depositional cycle. Both the Siberian and western Death Valley sections were locally deformed by westdirected thrust faults and folds prior to Late Neoproterozoic. These were reported by Khudoley and Guriev (2003) in the Sette Daban basin. We observed west-directed thrusts within the Beck Springs-KP1 section in the Ibex Hills that are overlain with angular unconformity by Kingston Peak diamictite (KP2 of Prave, 1999). These structures may record contraction in a Grenville foreland basin (e.g. Sears and Price, 2003; Timmons et al., 2005).

The Sette Daban and Death Valley Mesoproterozoic sections are overlain above a breakup unconformity by 10 $15 \mathrm{~km}$ thicknesses of Late Neoproterozoic to Triassic deposits that accumulated response to subsidence of passive continental margins (Evenchick et al., 2007; Khudoley and Guriev, 2003). In Siberia, the passive margin deposits define the Verkhoyansk miogeocline, and in North America, they define the Cordilleran miogeocline. In Sette Daban, the miogeoclinal deposits begin with the Yudoma Group, which is younger than a 647 Ma stock (Khudoley et al., 2007 and references therein), and pass upward into Early Cambrian beds (Fedonkin, 1992). In southwestern North America, the sequence begins with the 700-600 Ma (?) Kingston Peak diamictite, which accumulated in a rift system (Prave, 1999). The overlying siliciclastic-carbonate wedge includes the Noonday, Johnnie, Stirling, Wood Canyon, and Zabriskie formations in Death Valley, and the Wyman, Reed, Deep Spring, Campito, and Poleta formations in the White-Inyo region, deposited from late Neoproterozoic to Early Cambrian (Stewart, 1972; Levy and Christie-Blick, 1991; Link, 1993).

Fossils of the Cordilleran and Verkhoyansk miogeoclines include similar oncolites, Boxonia, Ediacaria, cloudiniids, archeocyathans, and ollenellid trilobites (Fedonkin, 1992; Signor et al., 1987; Hollingsworth, 2005). Both sections are characterized by several Neoproterozoic-Cambrian grand cycles from clastic to carbonate sedimentary rocks (Gevirtzman and Mount, 1986; Khudoley and Guriev, 2003); the basal two cycles have massive oncolitic dolomite members, and the upper ones have distinctive cross-bedded sandy dolomite and

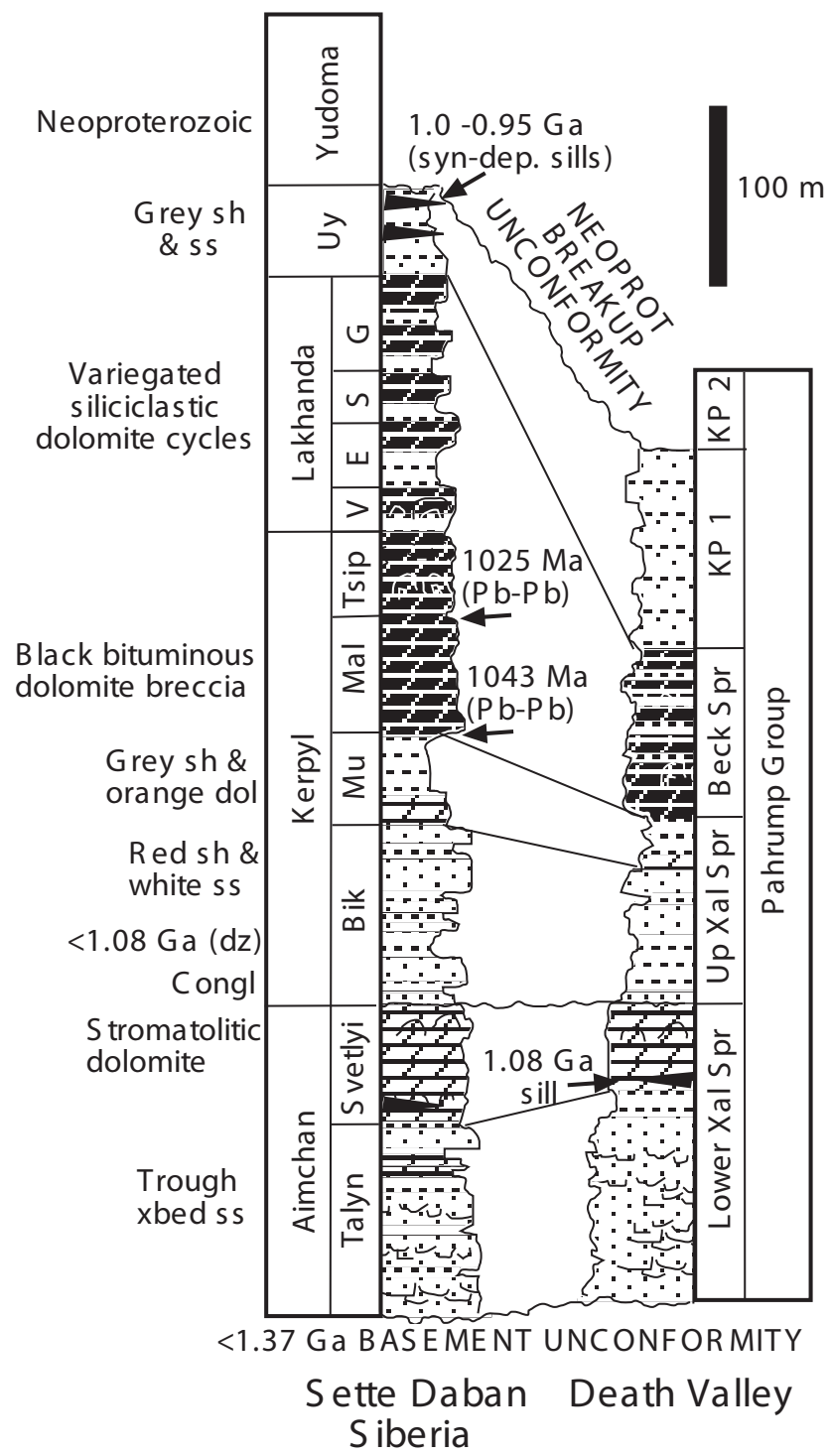

Fig. 2. Comparative Mesoproterozoic stratigraphy of Sette Daban and Death Valley regions. Sette-Daban section and ages after Khudoley et al. $(2001,2007)$ and references therein. Death Valley section after Wright et al. (1976) and unpublished data from Ibex Hills section measured by authors. Formation abbreviations: $\mathrm{Mu}=$ Muskel, Mal=Malgin, Tsip=Tsipanda, V=Vil, $\mathrm{E}=$ Eldikan, $\mathrm{S}=$ Salar, $\mathrm{G}=\mathrm{Gren}, \mathrm{Xal}=$ Crystal Spring.

feldspathic sandstone. Carbon isotope patterns support correlations of the sections (Corsetti and Kaufman, 2000). The southeast Siberian and southwest North American grand cycles evidently record correlative Neoproterozoic and Cambrian eustatic sea level changes phased with synchronous passive continental-shelf subsidence. Both passive margin successions were deformed into orogenic belts beginning in Jurassic time (Evenchick et al., 2007; Khudoley and Prokopiev, 2007). 


\section{Detrital zircon links}

Southeastern Siberian basement exposed in the Aldan shield includes mainly $2100-1850 \mathrm{Ma}$ and $>2300 \mathrm{Ma}$ provinces (Khudoley et al., 2007; Frost et al., 1998). Distinct southwestern North American basement age-provinces include the 1250-1000 Ma Grenville, 1500-1350 Ma GraniteRhyolite, and 1850-1650 Ma Mojave, Yavapai, and Mazatzal provinces (Van Schmus and Bickford, 1993; Farmer et al., 2005). Mojave province granites also contain $>2300$ Ma zircon xenocrysts (Farmer et al., 2005) that are not distinguishable in age from those of the Aldan shield.

Kerpyl and Uy sandstones of the Sette Daban basin contain large percentages of detrital-zircon grains that correlate with the North American Grenville, Granite-Rhyolite, and Mojave-Yavapai-Mazatzal basement provinces (Fig. 3). Furthermore, gaps in detrital-zircon ages coincide with age gaps in southwestern North American source rocks (e.g. Farmer et al., 2005). Detrital-zircon age-spectra from the Mesoproterozoic Unkar Group of the Grand Canyon provide a useful reference for Laurentian provenance age domains (Timmons et al., 2005). The similarity coefficients (Gehrels, 2000) of the detrital-zircon age-spectra from Siberian samples with respect to the Unkar Group reveal a dramatic increase in similarity upward in the stratigraphic section from the Aimchan Group (0.255) to the Uy Group (0.835) (Fig. 4). Paleocurrent and provenance data indicate that the Uy Group sandstones were derived from east or southeast of the Siberian craton (Khudoley et al., 2001), consistent with sediment sources in southwestern North America indicated by the reconstructed map (gray arrows in Fig. 1). The Uy Group records an increase in lithic fragments (see Khudoley et al., 2001) in concert with the increasing North American detrital zircon component.

The increase in detrital zircons of possible southwestern North American provenance accompanied subsidence of the Sette Daban basin at 1100 to 950 Ma (Khudoley et al., 2001). That subsidence was punctuated by mafic magmatic activity, approximately correlative with mafic magmatism in the southwestern United States (Heaman and Grotzinger, 1992), where it has been related to crustal extension in the Grenville foreland basin orthogonal to the Grenville front (Howard, 1991; Timmons et al., 2005). We suggest that an orthogonal rift channeled sediment from the Grenville orogen, across exposed southwestern North American basement provinces to the Sette Daban basin (Fig. 1).

By contrast, we found that $<600$ Ma-old miogeoclinal sandstones from the Sette Daban basin lacked North American detrital-zircon age suites (Figs. 3 and 4). This indicates sedimentary processes no longer transferred zirconbearing sand from North America to Siberia. The Grenville, Granite-Rhyolite, and Mojave-Yavapai-Mazatzal peaks remain prominent for our miogeoclinal samples from the Death Valley and White-Inyo regions (Kingston Peak, Stirling, Wyman, and Deep Spring formations) and are generally

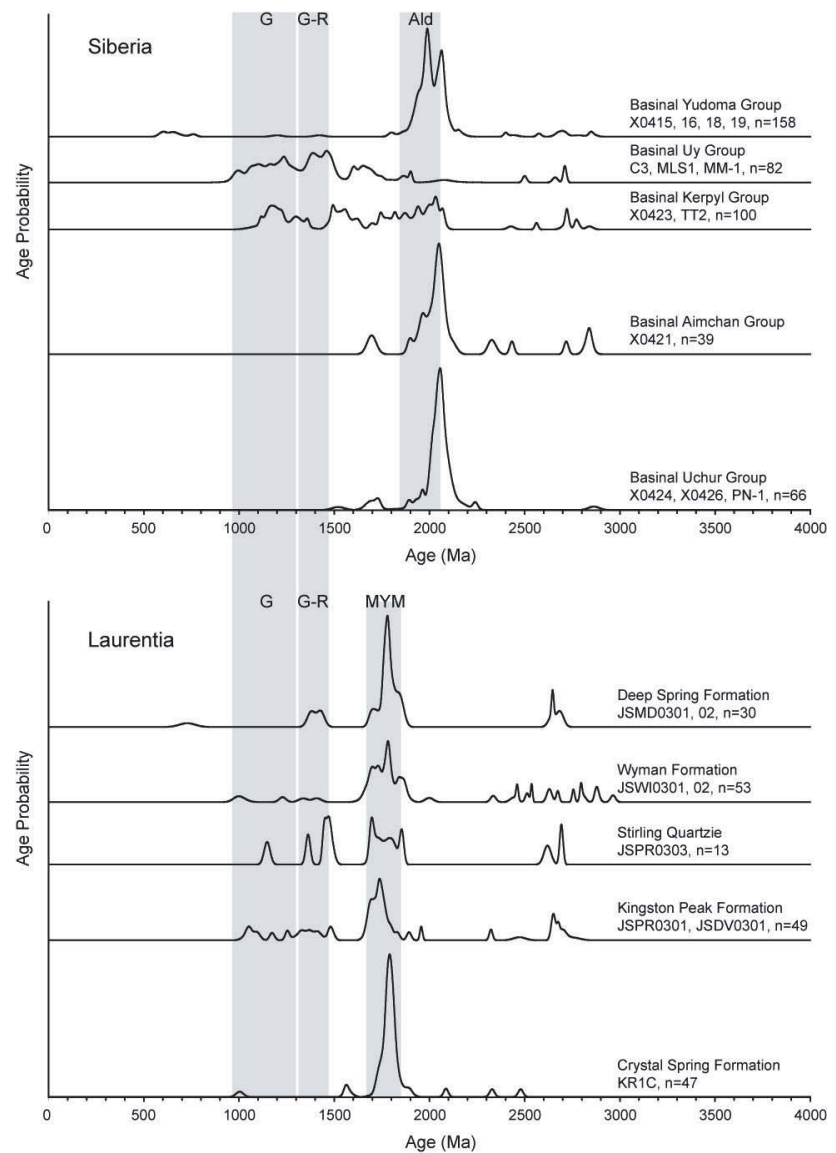

Fig. 3. Detrital-zircon age probability graphs for Sette Daban and Death Valley regions. Highlighted provenance terranes: $\mathrm{G}=$ Grenville, G-R=Granite Rhyolite, MYM=MojaveYavapai-Mazatzal, Ald=Aldan. MM-1 data from Rainbird et al. (1998). Uchur Group is Early Mesoproterozoic unit that locally underlies Aimchan Group. Data from MacLean (2007).

characteristic of Late Neoproterozoic sandstones of the Cordilleran miogeocline (e.g. Farmer et al., 2005). Figure 4 accentuates the abrupt decrease in the similarity coefficient across the breakup unconformity in Siberia, from 0.83 in the Uy Group to 0.27 in the post-breakup Yudoma Group.

We deduce that by Early Cambrian time, separation of the southeastern Siberian and southwestern North American cratons was sufficient to isolate segments of their rift margins from intercontinental sediment-mixing. Clastic sediment eroded from North America was trapped in kms-thick deposits on its new western continental shelf (Stewart, 1972), but the southeastern Siberian shelf was largely covered with carbonate and received only limited sand from its interior, and virtually none from North America. However, we suggest that the cratons remained close enough to allow transfer of Early Cambrian fauna. For example, despite characteristic endemism, the first trilobite to appear in North America 


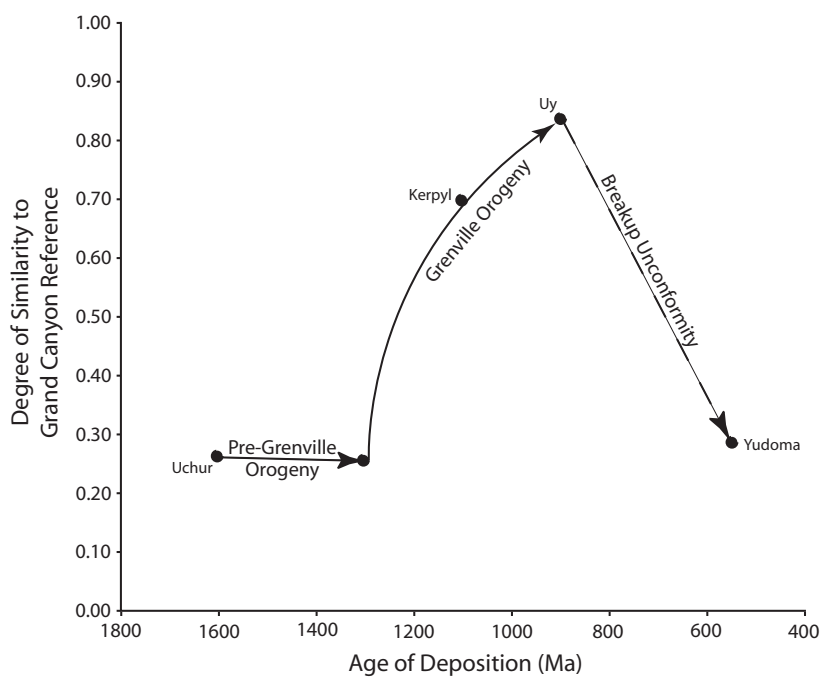

Fig. 4. Variation in degree of similarity (e.g. Gehrels, 2000) of Sette Daban detrital zircons to Grand Canyon Mesoproterozoic (Unkar Group) reference detrital zircon assemblages reported by Timmons et al. (2005). Identical assemblages would have similarity coefficient of 1.0. Degree of similarity increased upward in section from Aimchan (depositional age $\sim 1.3 \mathrm{Ga}$ ) to Kerpyl (depositional age $\sim 1.1 \mathrm{Ga}$ ) and Uy (depositional age $\sim 1.0-0.7 \mathrm{Ga}$ ) groups during Grenville orogeny, then abruptly decreased in Yudoma Group above breakup unconformity, after separation of Siberia from North America. Uchur Group is Early Mesoproterozoic unit that locally underlies Aimchan Group.

occurs in western Nevada and closely resembles the southeastern Siberian trilobite Repinaella (Hollingsworth, 2005), indicating that these areas were within trilobite breeding range in Early Cambrian time.

\section{Summary and conclusion}

We conclude that $\mathrm{Pb}-\mathrm{Pb}$ dates of detrital zircons in Proterozoic sandstones of the Sette Daban basin of the southeastern Siberia craton indicate that some of the sandstones may have been derived from provenance areas in southwestern North America during the Grenville orogeny. These results support a Proterozoic connection of the eastern Siberian craton to the western North American craton (Sears and Price, 2003). The sediment may have streamed into Siberia down a rift that opened orthogonally to the Grenville front. The reconstructed basin represents a rare remnant of a Grenville foreland trough. The possible North American detritalzircon provenance increased with time during the Grenville orogeny, but ceased by $600 \mathrm{Ma}$ when separation of the Siberian and North American was sufficient to block sediment. However, the cratons were close enough during Early Cambrian time for Siberian and North American trilobites to successfully interbreed.
Acknowledgements. This research was funded by NSF grants to Sears and Chamberlain, and by RFBR grants 05-05-65327, 06-0596070, 07-05-00743, and Integration Projects of Russian Academy of Sciences ONZ-7.10.2 to Khudoley and Prokopiev. Diamond and Precious Metal Geology Institute, Siberian Branch of Russian Academy of Sciences, and Yakutsk Metals Institute of Yakutia provided logistical support for the Belaya River expedition.

\section{References}

Abolins, M., Oskin, R., Prave, A., Summa, C., and Corsetti, F. A.: Neoproterozoic glacial record in the Death Valley region, California and Nevada (in Great Basin and Sierra Nevada), Field Guide, Geological Society of America, 2, 319-335, 2000.

Bowring, S. A., Grotzinger, J. P., Isachsen, C. E., Knoll, A. H., Pelechaty, S. M., and Kolosov, P.: Calibrating rates of Early Cambrian evolution, Science, 261, 1293-1298, 1993.

Condie, K. C. and Rosen, O. M.: Laurentia-Siberia connection revisited, Geology, 22, 168-170, 1994.

Corsetti, F. A. and Kaufman, A. J.: Chemostratigraphy of Neoproterozoic-Cambrian units, White-Inyo region, Eastern California and western Nevada, Implications for global correlation and faunal distribution, Palaios, 9, 211-219, 2000.

Ernst, R. E., Buchan, K. L., Hamilton, M. A., Okrugin, A. V., and Tomshin, M. D.: Integrated paleomagnetism and U-Pb geochronology of mafic dikes of the eastern Anabar Shield region, Siberia: Implications for Mesoproterozoic paleolatitude of Siberia and comparison with Laurentia, J. Geol., 108, 381-401, 2000.

Evenchick, C. A., McMechan, M. E., McNicoll, V. J., and Carr, S. D.: A synthesis of the Jurassic-Cretaceous tectonic evolution of the central and southeastern Canadian Cordillera:exploring links across the orogen, Geological Society of America, Special Paper, Special Paper 433, 2007.

Farmer, G. L., Bowring, S. A., Matzel, J., Espinosa Maldonado, G., Fedo, C., and Wooden, J.: Paleoproterozoic Mojave province in northwestern Mexico?, Isotopic and $\mathrm{U}-\mathrm{Pb}$ zircon geochronologic studies of Precambrian and Cambrian crystalline and sedimentary rocks, Caborca, Sonora, Geol. S. Am. S., 393, 183-198, 2005.

Fedonkin, M.A.: Vendian Faunas and the early evolution of metazoa, in: Origin and early evolution of the metazoa, Lipps, J. H. and Signor, P. W., Plenum Press, New York, 87-129, 1992.

Frost, B. R., Avchenko, O. V., Chamberlain, K. R., and Frost, C. D.: Evidence for extensive Proterozoic remobilization of the Aldan shield and implications for Proterozoic plate tectonic reconstructions of Siberia and Laurentia, Precambrian Res., 89, 1-23, 1998.

Gehrels, G. E.: Introduction to detrital zircon studies of Paleozoic and Triassic strata in western Nevada and northern California, Geol. S. Am. S., 347, 1-17, 2000.

Gevirtzman, D. A. and Mount, J. F.: Paleoenvironments of an Earliest Cambrian (Tommotian) shelly fauna in the southwestern Great Basin, USA, J. Sediment. Petrol., 56, 412-421, 1986.

Heaman, L. M. and Grotzinger, J. P.: $1.08 \mathrm{Ga}$ diabase sills in Pahrump Group, California: Implications for development of the Cordilleran miogeocline, Geology, 20, 637-640, 1992.

Hollingsworth, J. S.: The earliest occurrence of trilobites and brachiopods in the Cambrian of Laurentia, Palaeogeogr. Palaeocl., 220, 153-165, 2005. 
Hoffman, P. J.: Did the breakout of Laurentia turn Gondwanaland inside-out?, Science, 252, 1409-1412, 1991.

Howard, K. A.: Intrusion of horizontal dikes: Tectonic significance of Middle Proterozoic diabase sheets widespread in the upper crust of the southwestern United States, J. Geophys. Res., 96(B), 12 461-12 478, 1991.

Khudoley, A. K., Rainbird, R. H., Stern, R. A., Kropachev, A. P., Heaman, L. M., Zanin, A. M., Podkovyrov, V. N., Belova, V. N., and Sukhorukov, V. I.: Sedimentary evolution of the RipheanVendian basin of southeastern Siberia, Precambrian Res., 111, 129-163, 2001.

Khudoley, A. K., Kropachev, A. P., Tkachenko, V. I., Rublev, A. G., Sergeev, S. A., Matukov, D. I., and Lyahnitskaya, O. Yu.: Mesoto Neoproterozoic evolution of the Siberian craton and adjacent microcontinents: an overview and restrictions for Rodinia reconstructions, in: Proterozoic geology of western North America and Siberia, edited by: Link, P. K. and Lewis, R., SEPM Special Publication, 86, 275 pp., 2007.

Khudoley, A. K. and Guriev, G. A.: Influence of synsedimentary faults on orogenic structure: Examples from the NeoproterozoicMesozoic east Siberian passive margin, Tectonophysics, 365, 23-43, 2003.

Khudoley, A. K. and Prokopiev, A. V.: Defining the eastern boundary of the North Asian craton from structural and subsidence history studies of the Verkhoyansk fold-and-thrust belt, in: Whence the Mountains? Inquiries into the evolution of orogenic systems: A volume in honor of Raymond A. Price, edited by: Sears, J. W., Harms, T. A., and Evenchick, C. A., Geol. S. Am. S., 433, 391-410, 2007.

Kirshvink, J. L., Ripperdan, R. L., and Evans, D. A.: Evidence for a large-scale reorganization of Early Cambrian continental masses by inertial interchange true polar wander, Science, 277, 541-545, 1997.

Levy, M. and Christie-Blick, N.: Tectonic subsidence of the early Paleozoic passive continental margin in eastern California and southern Nevada, Geol. Soc. Am. Bull., 103, 1590-1606, 1991.

Levy, M. and Christie-Blick, N.: Pre-Mesozoic palinspastic restoration of the eastern Great Basin, in: Precambrian: Continental US, Boulder, Colorado, edited by: Reed, J. C., Bickford, M. E., Houston, R. S., et al., Geological Society of America, Geology of North America, C-2, plate in pocket (first published in Science, 245(4925), 1454-1462, 1989), 463-595, 1992.

Link, P. K. (Ed.): Middle and Late Proterozoic stratified rocks of western US Cordillera, Colorado Plateau, Basin and Range province, in: Precambrian: Continental US, Boulder, Colorado, edited by: Reed, J. C., Bickford, M. E., Houston, R. S., et al., Geological Society of America, Geology of North America, C-2, 463-595, 1993.

MacLean, J. S.: Detrital-zircon geochronological provenance analyses that test and expand the east Siberia-west Laurentia Rodinia reconstruction, Ph.D. Dissertation, University of Montana, 173 pp., 2007.

Prave, A. R.: Two diamictites, two cap carbonates, two delta (super 13) C excursions, two rifts; the Neoproterozoic Kingston Peak Formation, Death Valley, California, Geology, 27, 339342, 1999.

Rainbird, R. H., Stern, R. A., Khudoley, A. K., Kropachev, A. P., Heaman, L. M., and Sukhorukov, V. I.: U-Pb geochronolgy of Riphean sandstone and gabbro from southeast Siberia and its bearing on the Laurentia-Siberia connection, Earth Planet. Sc. Lett., 164, 409-420, 1998.

Sears, J. W. and Price, R. A.: The Siberian connection: A case for the Precambrian separation of the North American and Siberian cratons, Geology, 6, 267-270, 1978.

Sears, J. W. and Price, R. A.: Tightening the Siberian connection to western Laurentia, Geol. Soc. Am. Bull., 115, 943-953, 2003.

Signor, P. W., Mount, J. F., and Onken, B. R.: A pre-trilobite shelly fauna from the White-Inyo region of eastern California and western Nevada, J. Paleontol., 61, 425-438, 1987.

Stewart, J. H.: Initial deposition in the Cordilleran Geosyncline: Evidence of a Late Precambrian (>850 m.y.) continental separation, Geol. Soc. Am. Bull., 83, 1345-1360, 1972.

Timmons, J. M., Karlstrom, K. E., Heizler, M. T., Bowring, S. A., Gehrels, G. E., and Crossey, L. J.: Tectonic inferences from the ca. 1255-1100 Ma Unkar Group and Nankoweap Formation, Grand Canyon: Intracratonic deformation and basin formation during protracted Grenville orogenesis, Geol. Soc. Am. Bull., 117, 1573-1595, 2005.

Van Schmus, W. R. and Bickford, M. E.: Transcontinental Proterozoic provinces, in: Precambrian: Continental US Boulder, Colorado, edited by: Reed, J. C., Reed, J. C., Bickford, M. E., Houston, R. S., et al., Geological Society of America, Geology of North America, C-2, 171-334, 1993.

Wright, L. A., Troxel, B. W., Williams, E. G., Roberts, M. T., and Diehl, P. E.: Precambrian sedimentary environments of the Death Valley region, eastern California, in: Geologic features of Death Valley, California, edited by: Troxel, B. W. and Wright, L. A., California Division of Mines and Geology Special Report, 106, 7-15, 1976. 